Acta vet. scand. 1988, 29, 207-218.

From the Department of Obstetrics and Gynaecology and the Department of

Clinical Chemistry, Faculty of Veterinary Medicine,

Swedish University of Agricultural Sciences, Uppsala, Sweden.

\title{
The Effect of Transportation/Relocation on Cortisol, CBG and Induction of Puberty in Gilts with Delayed Puberty
}

\author{
By A.-M. Dalin, L. Nyberg, and L. Eliasson
}

\begin{abstract}
Dalin, A.-M., L. Nyberg, and L. Eliasson: The effect of transportation/relocation on cortisol, CBG and induction of puberty in gilts with delayed puberty. Acta vet. scand. 1988, 29, 207-218. - Twenty-seven Swedish purebred Yorkshire gilts were transported $12 \mathrm{~km}$ to the clinic. In 8 gilts (Group A), blood samples were drawn in connection with transportation, while in the remaining 19 gilts (Group B) no samples were drawn at this time. After transportation the gilts were examined by laparoscopy and catheterized. Blood samples were then drawn 3 times and oestrus detection was performed twice daily. After 1 week the laparoscopy was repeated.

Twenty gilts (74\%) showed oestrus within 1 week, on average 5.4 days (4-7.5 days) after transportation. Elevated oestradiol- $17 \beta$ levels were seen in those gilts approximately 2 days after transportation. The cortisol level was significantly higher $(p<$ 0.001 ) on day 1 (the day of transportation) than on day 2 and a markedly higher level of cortisol was seen on days 1 and 2 in the gilts which did not show oestrus (2 gilts), compared with the gilts in which oestrus was induced (6 gilts) by transportation. The difference was significant on day $2(\mathrm{p}<0.05)$. The CBG level was significantly decreased ( $p<0.001$ ) on day 2 for all 8 gilts. During day 3 to day 8 there was no difference in the cortisol level between days (groups A and B, 27 gilts), and no differences were seen in the levels of cortisol and CBG between gilts showing (20 gilts) and not showing oestrus ( 7 gilts). The hypothesis propounded that the higher levels of cortisol on days 1 and 2 inhibited induction of oestrus in those gilts which did not show oestrus after transportation.
\end{abstract}

\section{Introduction}

Transportation including mixing and relocation has long been known to stimulate the induction of puberty in gilts (e.g. Paredis 1961, Du Mesnil du Buisson \& Signoret 1962). Dalin \& Eliasson (1987) studied the effect of transportation in gilts with delayed puberty (i.e. gilts more than 8 months of age which have not shown oestrus). They found that $70 \%$ of the gilts showed oestrus within
1 week after transportation and relocation. In the gilts showing oestrus, elevated levels of oestradiol-17 $\beta$ were found in the peripheral blood soon after arrival at the new place. Transportation of pigs will expose the animals to stress as indicated by elevated levels of cortisol (Spencer et al. 1984, Becker et al. 1985a, Nyberg et al. 1987). Cortisol is present in blood plasma in a protein-bound form, mainly bound to corticosteroid-bind- 
ing globulin (CBG), and in an unbound (free) fraction which is considered to be the biologically active portion (see review: Siiteri et al. 1982). Stress has a stimulatory effect on puberty in those gilts that attain puberty after transportation, while some animals do not show oestrus after transportation/change of environment. In what way do these latter animals differ from those in which puberty is induced? Barb et al. (1982) showed that injection with ACTH or hydrocortisone block the preovulatory surge of $\mathrm{LH}$ and ovulation in cycling gilts.

Furthermore, in most domestic animals stress due e.g. to transportation, change of environment, grouping and/or management is considered to have a harmful effect on reproduction in the form of delayed ovulation, changed oestrus cycle, etc. (see review: $\mathrm{Mo}$ berg 1985).

The aim of this investigation was to correlate cortisol and CBG levels with puberty response in gilts with delayed puberty that had been subjected to transportation and relocation.

\section{Material and methods}

This investigation, which was carried out during 1983-1986, used halothane-negative gilts (see Eliasson et al. 1987) of Swedish purebred Yorkshire, reared at a research station belonging to the Department of Animal Breeding and Genetics. At the research station the gilts were restrictedly fed. Oestrus detection was done twice daily from 160 days of age. Blood samples for progesterone determination were taken every 10th day from 170 days of age. From this age the gilts were also exposed to a boar. The boar was kept in an adjacent pen and moved once a day to the gilt pens.

The gilts which had not shown oestrus at the age of 8 months or more were transported to the clinic at the Department of Obstetrics and Gynaecology, a journey of $12 \mathrm{~km}$ (for detail see: Dalin \& Eliasson 1987). After arrival at the clinic, the gilts were examined by laparoscopy (Wildt et al. 1973). Twentyseven gilts had only small follicles $(<6 \mathrm{~mm})$ in the ovaries and were used in the present investigation. The gilts' mean age was 260.0 days ( $\mathrm{SD}=17.6$, range $237-289$ days) on arrival to the clinic. The feed at the clinic (Eriksson et al. 1972) was about the same as at the research station.

Blood samples were collected in vacutainer tubes from the v. jugularis in 8 (Group A) restrained animals immediately before and after transportation and 30 min after arrival at the clinic. The transportations were done at 8.30 a.m. and loading/unloading and transportation took about $30 \mathrm{~min}$. No blood samples were drawn in connection with transportation from 19 of the gilts (Group B).

Within $5 \mathrm{~h}$ (Group A) and $20 \mathrm{~h}$ (Group B) after arrival, the gilts were examined by laparoscopy and a permanent catheter was inserted into the jugular vein for blood sampling (Rodriguez \& Kunavongkrit 1983). The operation was performed under general anaesthesia (pentothal-sodium, $5 \%$ ). The gilts were then placed in individual pens with sexually mature boars kept in adjacent pens. Oestrus detection was done twice daily and blood samples were drawn 3 times daily (9 a.m., 12 noon and 3 p.m.) during 1 week. Laparoscopy was repeated one week after transportation.

All blood samples were collected in heparinized tubes and centrifuged as soon as possible. The plasma was then stored at $-18^{\circ} \mathrm{C}$ until assay.

\section{Hormone assay}

Blood plasma levels of $\mathrm{LH}$ were determined by radioimmunoassay. An antiserum to ovine LH (Nisvender et al. 1969) was used for 
the assay system. Porcine LH (LER-786-3) was used for radioiodination by the chloramine-T method and as standard. The use of these reagents for radioimmunoassay of porcine LH has been described in an earlier study (Niswender et al. 1970). Separation of free and antibody-bound hormone was made with a second antibody to rabbit gammaglobulin coupled to a solid phase (DASP, Organon, The Netherlands). The analyses of pooled plasma in 19 assays resulted in a mean value of $1.05 \mu \mathrm{g} / \mathrm{l}(\mathrm{SD}=0.29 \mu \mathrm{g} / \mathrm{l})$. All values presented represent the mean of duplicate determinations.

Progesteron and oestradiol-17 $\beta$ were determined by radioimmunoassay (Edqvist \& $J o-$ hansson 1972), using antisera to 11- $\alpha$-hydroxyprogesterone (Bosu et al. 1976) and 6-keto-oestradiol-17 $\beta$ (Boilert et al. 1973). The analyses of pooled plasma in 22 assays resulted in mean values of $1.14 \mathrm{nmol} / 1(\mathrm{SD}=$ $0.36 \mathrm{nmol} / \mathrm{l})$ and $29 \mathrm{pmol} / \mathrm{l}(\mathrm{SD}=5.4$ $\mathrm{pmol} / \mathrm{l}$ ) for progesterone and oestradiol-17 $\beta$, respectively. All oestradiol-17 $\beta$ values represent the mean of duplicate determinations. On the basis of analyses of plasma samples from an ovariectomized sow, we have previously determined the practical detection limit of this assay to be $24 \mathrm{pmol} / 1$ (Andersson et al. 1983).

Cortisol levels were measured by direct radioimmunoassay according to Nyberg et al. (1987). The antiserum was produced in rabbits against cortisol-21-succinyl-BSA and cross-reacted with corticosterone $(25 \%)$, 21-hydroxyprogesterone (4\%) and progesterone $(12 \%)$. Inter and intra-assay coefficients of variation were $9.4 \%(n=10)$ and $7 \%$ $(\mathrm{n}=8)$, respectively, at a plasma cortisol concentration of $45 \mathrm{nmol} / \mathrm{l}$. The CBG binding capacity was estimated as a one-point assay according to Lundström et al. (1983), with modification by Nyberg et al. (1987). All samples were analyzed for cortisol. CBG was analyzed in all samples on day 1 and 2 for group A gilts. From day 3 to day 8 (groups A and B) only one sample a day (9 a.m.) was analyzed for CBG. Previous studies (Nyberg, unpublished) have shown that the CBG level has no diurnal variation as contrasted to the diurnal rhythm observed for cortisol levels (e.g. Engqvist et al. 1980, Becker et al. 1985a).

\section{Statistical analyses}

The statistical analyses were performed using the Statistical Analyses System ( $S A S$ Institute Inc. 1985). The following model was assumed to describe the data:

$Y_{i j k l m}=\mu+o_{i}+g_{i j}+d_{k}+t_{1}+e_{i j k l m}$ where:

$\mathrm{Y}_{\mathrm{ijk} \mathrm{km}}=$ the $\mathrm{ijklm}{ }^{\text {th }}$ observation

$\mu \quad=$ general mean

$o_{i} \quad=$ the effect of the $i^{\text {th }}$ oestrus $(i=1,2)$

$\mathrm{g}_{\mathrm{ij}} \quad=$ the effect of the $\mathrm{j}^{\text {th }}$ gilt in the $\mathrm{i}^{\text {th }}$ oestrus $(j=1,2, \ldots 8$ or $j=1,2, \ldots 27)$

$d_{k}=$ the effect of the $k^{\text {th }}$ sampling day $(\mathrm{k}=1,2$, or $\mathrm{K}=3-8)$

$t_{1}=$ the effect of the $1^{\text {th }}$ time of the day $(\mathrm{t}=1,2,3)$

$\mathrm{e}_{\mathrm{ijk} k \mathrm{~m}}=$ the residual random term, $\mathrm{N}\left(0, \sigma_{\mathrm{e}}^{2}\right)$

All effects, except the gilts and residuals, were regarded as fixed. The animals were analyzed in two separate stages using the above model;

I. Group A (8 gilts). Samples from days 1 and 2 were used.

II. Group A and B (27 gilts). All animals were analyzed together using samples from day 3 to day 8 . In addition, when only animals showing oestrus were analyzed $(n=20)$, the days before and during the oestrus cycle were used instead ( -3 to 3$)$. In both stages separate analyses were performed for each day. Due to the design of the model, the effect of oestrus was tested using the mean squares for gilts as error term. 


\section{Results}

The effect of transportation on puberty and blood levels of LH, oestradiol-17 $\beta$ and progesterone in Group B gilts has been reported earlier (Dalin \& Eliasson 1987).

Twenty gilts showed oestrus 5.4 days (range 4-7.5 days) after arrival and at the second laparoscopy, corpora lutea or matured follicles were seen in their ovaries. The mean age at first oestrus was 266.7 days (range 244-295 days). In Group A there was a rise in the oestradiol-17 $\beta$ level ( $>30 \mathrm{pmol} / \mathrm{l}$ ) and in the LH level (pre-ovulatory peak) at an average of $46 \mathrm{~h}$ (range 24-54 h) and $94 \mathrm{~h}$ (range 78-128 h), respectively, after transportation in the 6 gilts which showed oestrus. In Group B gilts, no blood samples were taken at transportation and the sampling was begun after the catheter operation, which was done within $20 \mathrm{~h}$ after transpor- tation. In the 14 gilts which showed oestrus, a rise in the oestradiol-17 $\beta$ level was observed at an average of 1.9 days (0-5 days) and a rise in the $\mathrm{LH}$ was seen at an average of 4.5 days (3-7 days) after the start of blood sampling. Fig. 1 shows the hormonal pattern of oestradiol-17 $\beta, \mathrm{LH}$ and progesterone in one representative gilt in which puberty was induced by transportation (Group A). In 7 gilts (Groups A and B), no changes in follicular size could be observed at the second laparoscopy and no rise in oestradiol-17 $\beta$ or LH $(<1 \mu \mathrm{g} / \mathrm{l})$ was found during the observation period.

The transportation caused an immediate rise in the blood level of cortisol. The level remained high on the day of transportation and relocation, but thereafter returned to lower levels. The CBG level did not change during day 1 but a significant decrease was

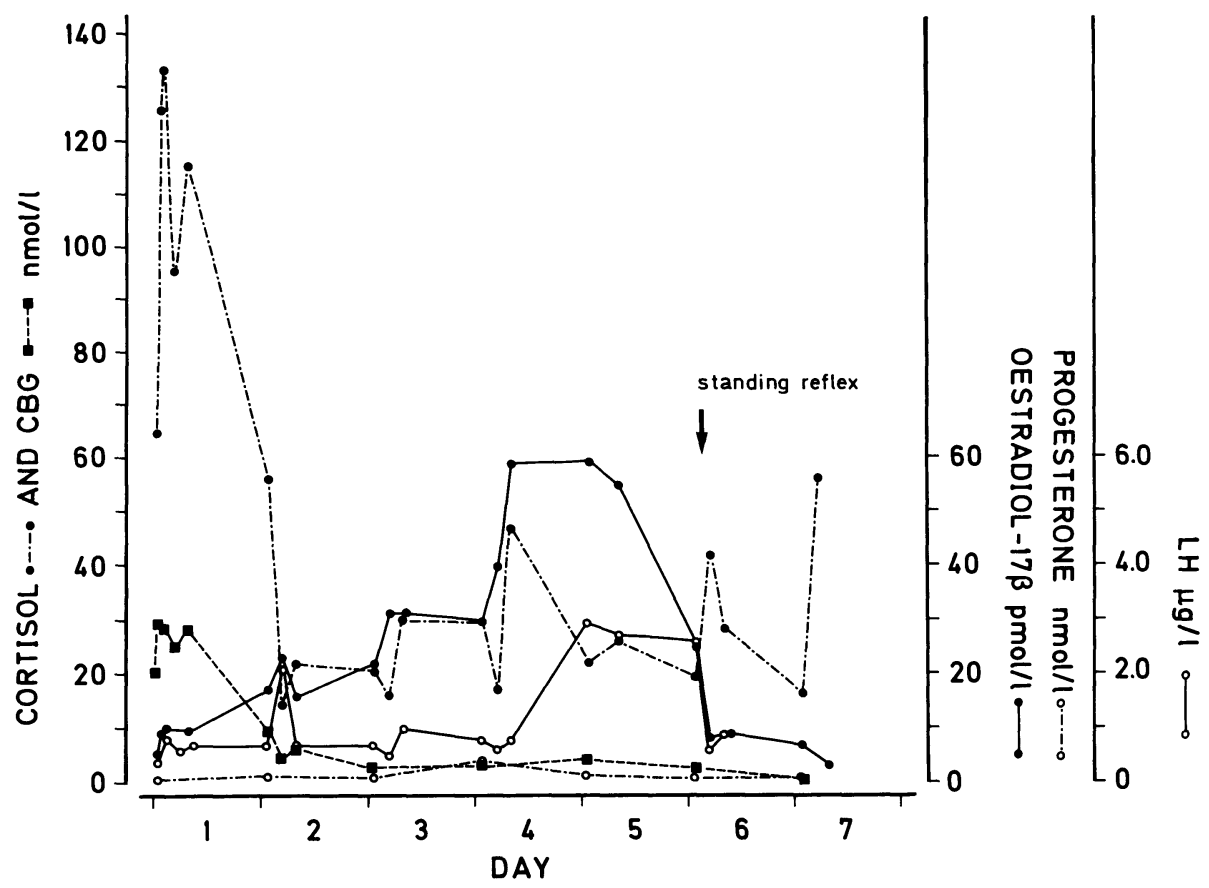

Figure 1. Cortisol, CBG, oestradiol-17 $\beta, \mathrm{LH}$ and progesterone levels in one gilt showing oestrus within 1 week after transportation. 
Table 1. Least-square means for cortisol and CBG during day 1 and day 2 and levels of significance for the effects studied (Group A, 8 gilts).

\begin{tabular}{lcccccccc}
\hline & \multicolumn{2}{c}{ Least/square means nmol/1 } & & \multicolumn{4}{c}{ Level of significance } \\
\cline { 2 - 3 } \cline { 6 - 8 } & Day 1 & Day 2 & & Oestrus & Gilt & Day & Time \\
\hline Cortisol & $98.9^{\mathrm{a}}$ & $43.4^{\mathrm{b}}$ & & NS & $* * *$ & $* * *$ & $* * *$ \\
CBG & $28.7^{\mathrm{a}}$ & $15.4^{\mathrm{b}}$ & & NS & $* * *$ & $* * *$ & NS \\
\hline
\end{tabular}

$$
\begin{aligned}
& \text { Levels of significance: } \\
& \mathrm{NS}=\mathrm{p}>0.05 \quad * *=\mathrm{p} \leq 0.01 \\
& *=\mathrm{p} \leq 0.05 \quad * * *=\mathrm{p} \leq 0.001
\end{aligned}
$$

means with the same letter are not significantly different $(p>0.05)$

found on day 2. The patterns of cortisol and CBG in the peripheral blood for one gilt are presented in Fig. 1. The levels of significance for the effects studied and the least square means for cortisol and CBG during days 1 and 2 (Group A; 8 gilts) are presented in Table 1. Both cortisol and CBG levels were lower the day after transportation, compared with the day of transportation (43.4 versus $98.9 \mathrm{nmol} / 1, \mathrm{p}<0.001$ and 15.4 versus $28.7 \mathrm{nmol} / \mathrm{l}, \mathrm{p}<0.001$ ). There was a significant difference between individuals for both cortisol and CBG and cortisol levels differed significantly with time, while CBG levels did not (Table 1). A highly significant correlation $(0.65, \mathrm{p}<0.001)$ between cortisol and CBG levels was seen on days 1 and 2. Higher levels of cortisol and CBG on days 1 and 2 were seen in the gilts which did not show oestrus after transportation. The cortisol levels in gilts showing oestrus and not showing oestrus within one week after transportation were 80.0 versus 124.0 $\mathrm{nmol} / \mathrm{l}(\mathrm{p}>0.05)$ on day 1 , and 27.5 versus $50.3 \mathrm{nmol} / \mathrm{l}$ on day $2(\mathrm{p}<0.05)$ respectively. No significant differences in CBG levels within days could be observed between gilts showing oestrus and not showing oestrus (Fig. 2).
The least-square means of cortisol and CBG for all gilts (Groups A and B) during day 3 to day 8 at 9 a.m. are presented in Table 2 . The levels of both cortisol and CBG varied between animals $(p<0.001)$. The daily variations of cortisol were 37.3 to 44.0 $\mathrm{nmol} / \mathrm{l}$ and of CBG 19.6 to $23.6 \mathrm{nmol} / \mathrm{l}$. The variation betwen days was significant for CBG ( $p<0.05$ ) but not for cortisol. The least-square means of cortisol and CBG for gilts showing and not showing oestrus are presented separately in Fig. 3. No significant differences were found from day 3 to day 8 between gilts in which oestrus was induced and not induced (Table 2). The correlation (Table 3) between cortisol and CBG was highly significant in the 27 gilts from day 3 to day 8 .

The least-square means of oestradiol-17 $\beta$, $\mathrm{LH}$, cortisol and CBG levels, centred around the first day of oestrus, i.e. day 1 , for 20 gilts showing oestrus within one week, are shown in Fig. 4. The cortisol level rose significantly from day -3 to day $1(\mathrm{p}<0.01)$ and decreased significantly $(\mathrm{p}<0.001)$ from day 1 to day 2 in the oestrus cycle. The CBG level was significantly higher during the days before oestrus (days -1 and -2 ) than the day after (day $2, \mathrm{p}<0.01$ ). In the 20 gilts show- 


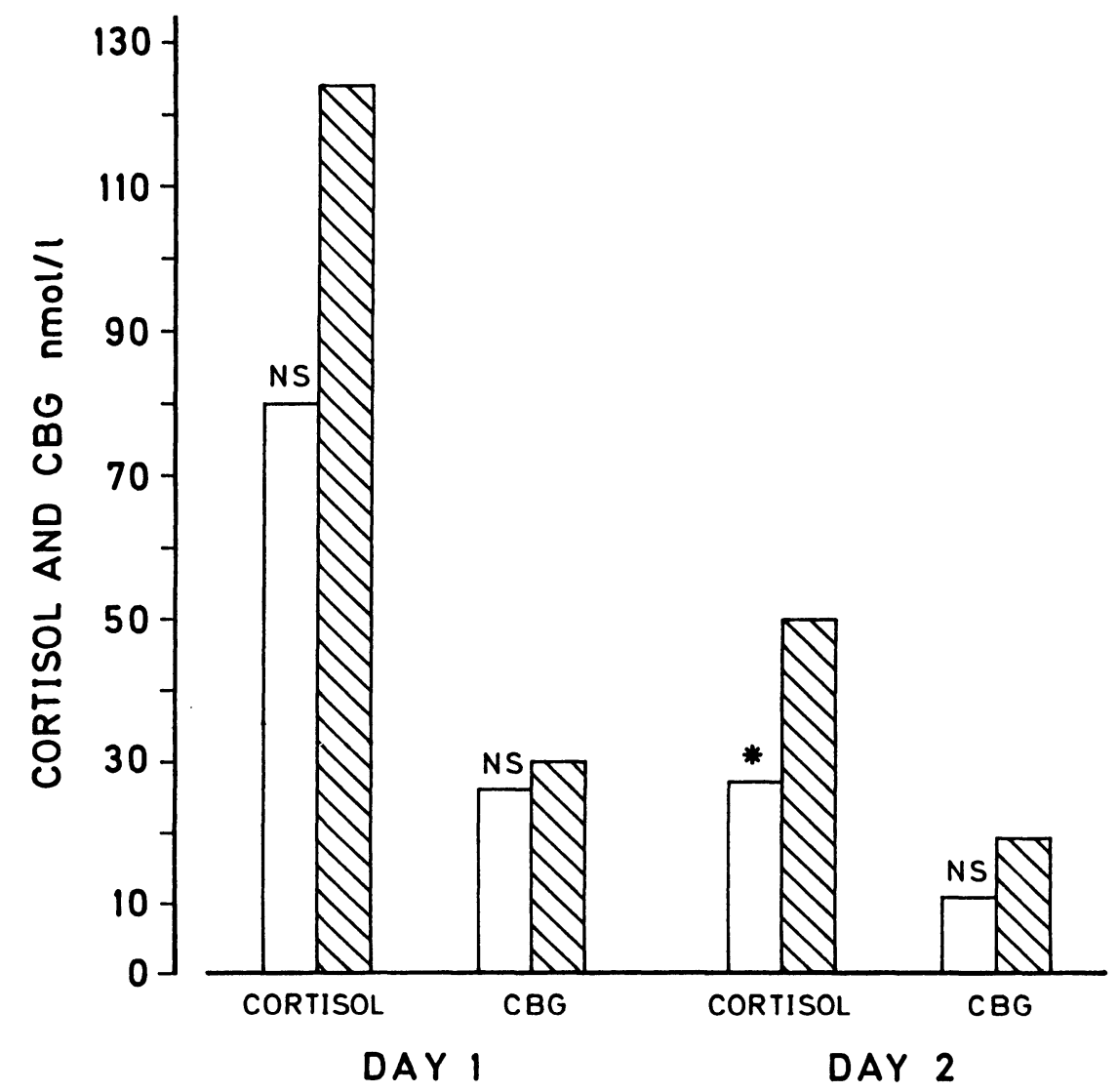

Figure 2. Least-square means of cortisol and CBG on days 1 and 2 in 6 gilts showing oestrus (open columns) and 2 gilts not showing oestrus (hatched columns) within 1 week after transportation.

Table 2. Last-square means for cortisol and CBG during day 3 to 8 and levels of significance for the effects studied (Groups A and B, 27 gilts).

\begin{tabular}{|c|c|c|c|c|c|c|c|c|c|c|}
\hline & \multicolumn{6}{|c|}{ Least-square means for sampling day $\mathrm{nmol} / \mathrm{l}$} & \multicolumn{4}{|c|}{ Level of significance } \\
\hline & 3 & 4 & 5 & 6 & 7 & 8 & Oestrus & Gilt & Day & Time \\
\hline Cortisol & $39.1^{\mathrm{ab}}$ & $44.0^{\mathrm{a}}$ & $42.5^{\mathrm{ab}}$ & $43.7^{\mathrm{ab}}$ & $37.8^{\mathrm{b}}$ & $37.3^{b}$ & NS & $* * *$ & NS & NS \\
\hline CBG & $21.9^{\mathrm{ab}}$ & $22.4^{\mathrm{a}}$ & $23.6^{\mathrm{a}}$ & $22.6^{\mathrm{a}}$ & $20.0^{\mathrm{b}}$ & $19.6^{\mathrm{b}}$ & NS & $* * *$ & $*$ & - \\
\hline
\end{tabular}

Levels of significance:

$\mathrm{NS}=\mathrm{p}>0.05$

** $=\mathrm{p} \leq 0.01$

* $=\mathrm{p} \leq 0.05$

$* * *=\mathrm{p} \leq 0.001$

means with the same letter are not significantly different $(p>0.05)$ 


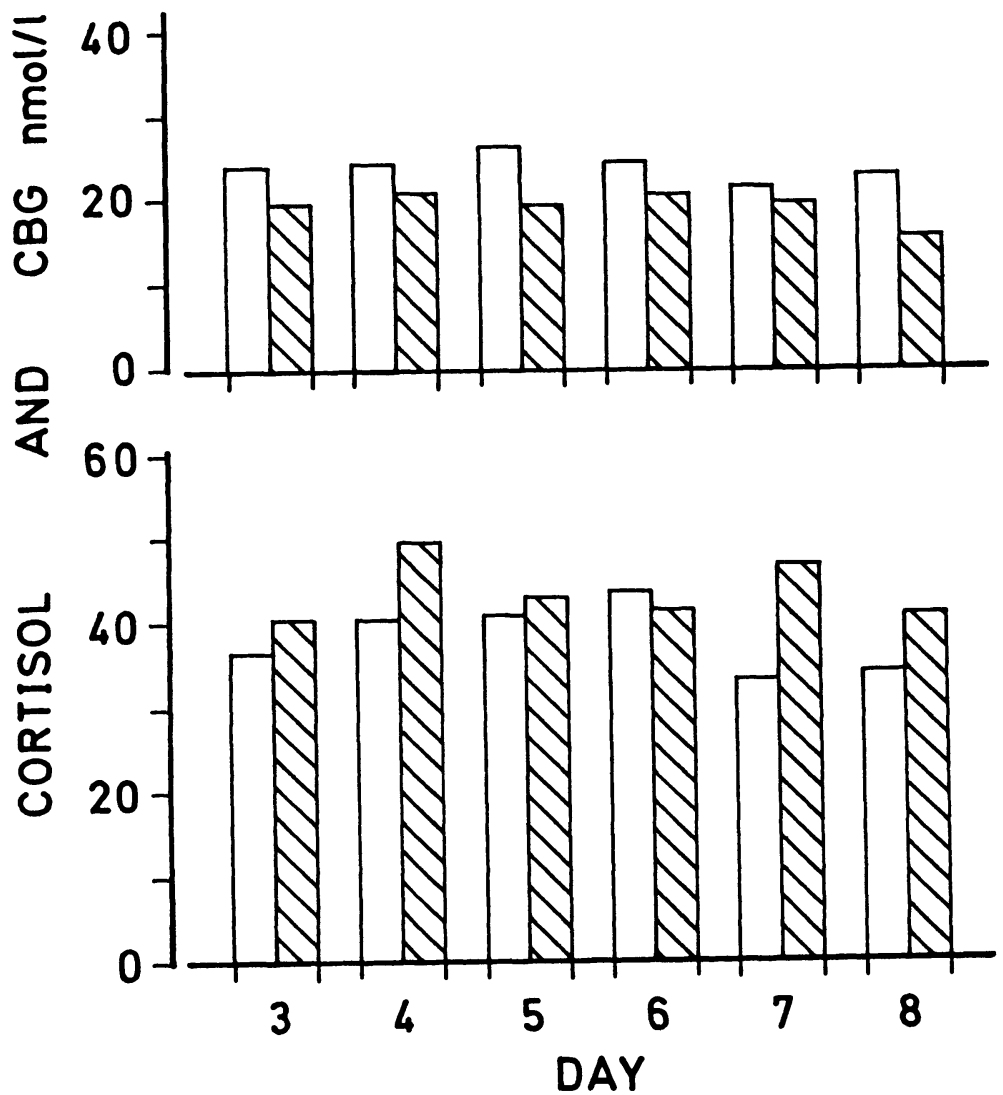

Figure 3. Least-square of cortisol and CBG on day 3 to day 8 in 20 gilts showing oestrus (open columns) and 7 gilts not showing oestrus (hatched columns) within 1 week after transportation.

Table 3. Correlations between cortisol, CBG, oestradiol-17 $\beta$ and LH during day 3 to day 8 .

\begin{tabular}{llrl}
\hline & Cortisol & \multicolumn{1}{c}{ CBG } & Oestrus \\
\hline LH & 0.03 & -0.07 & $0.14^{*}$ \\
Oestrus & $0.13^{*}$ & 0.04 & \\
CBG & $0.32^{* * *}$ & & \\
\hline
\end{tabular}

ing oestrus, the correlation between cortisol and oestradiol-17 $\beta$ levels was significant ( $p$ $<0.05$, Table 3 ).

\section{Discussion}

The result in Group A concerning the time elapsing from transportation to the occurrence of raised levels of oestradiol-17 $\beta$ and LH did not differ from those in Group B which have been presented earlier (Dalin \& Eliasson 1987). For this reason, surgery within 5 or $20 \mathrm{~h}$ did not change the results. The stress to which the gilts are exposed during the actual surgery is not enough to stimulate induction of oestrus. This has been 


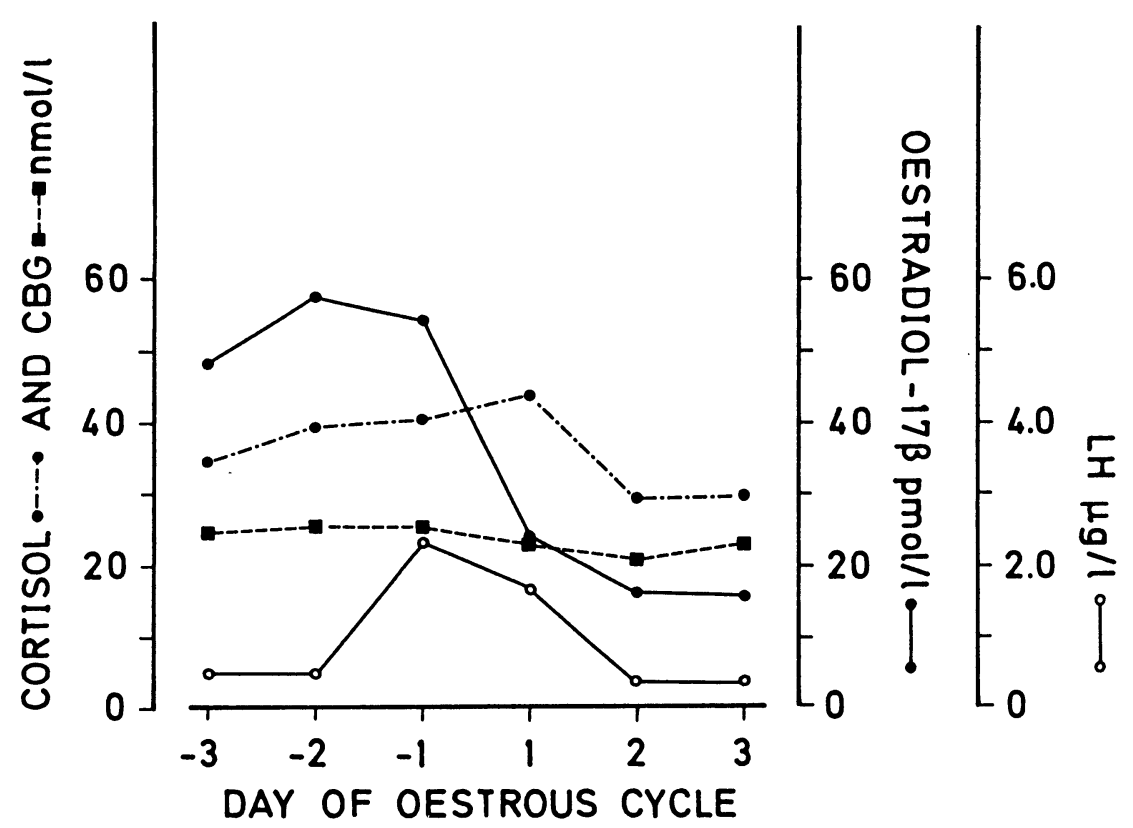

Figure 4. Least-square means of cortisol, CBS, oestradiol-17 $\beta$ and LH levels in 20 gilts showing oestrus after transportation (Day $1=$ the first day of oestrus).

found in gilts (own experience) and in anoestrous sows (Rojanasthien 1987).

In this study, the correlation between cortisol and CBG was highly significant both on days 1 and 2 and from day 3 to day 8 . The cortisol level was always higher than the CBG level and a free, biologically active cortisol level was therefore always present. On day 1 and day 2, however, the difference between cortisol and CBG levels was greater than during day 3 to day 8 , indicating a higher free cortisol level. The CBG level was unchanged during the observation period, except for a significant decrease on the day after transportation (day 2). The mechanisms behind the decrease in CBG levels and the physiological significance of the decreased level are not known.

The stress effect of transportation/relocation can be divided into two stages, the "emergency syndrome", involving the sympatho- adrenal system, and the "general adaption syndrome", involving the hypothalamic-hypophyseal-adrenal axis. It is the latter stage which is investigated when the cortisol levels are studied. In an experiment where the aim was to imitate transportation stress on pigs, Johansson et al. (1982) showed that the catecholamine level increased, which is an affect on the sympatho-adrenal system.

In the present study, the cortisol level was increased on the day of transportation and relocation, which is in agreement e.g. with Becker et al. (1985a). Transportation and relocation had a marked stimulating effect on the attainment of puberty; $74 \%$ of the gilts showed oestrus within 1 week. Elevated levels of oestradiol-17 $\beta$ were seen in the peripheral plasma at an average of $46 \mathrm{~h}$ after transportation in Group A gilts. Rojanasthien (1987) measured the oestradiol-17 $\beta$ level in the utero-ovarian vein in anoestrous sows 
before and after transportation. He found elevated oestradiol-17 $\beta$ levels in the uteroovarian vein plasma within 8 to $16 \mathrm{~h}$ after transportation. The effect of transportation on induction of puberty and oestrous is likely to be immediate. No difference in the cortisol and CBG levels during day 3 to day 8 was found between animals showing oestrus and not showing oestrus within 1 week after transportation. However, a marked difference in the cortisol level (Fig. 2) between the two groups was seen on days 1 and 2 but the difference was significant only on day 2 . Due to the big differences in cortisol levels between individuals, the groups were too small to show a significant difference on day 1. Schilling \& von Rechenberg (1973) and Barb et al. (1982) found that treatment with ACTH or glucocorticoids blocked ovulation in cycling gilts. Furthermore, Barb et al. (1982) showed that the preovulatory peak of LH was blocked. It may therefore be hypothesized that a too high cortisol level during transportation/relocation inhibits an increase in $\mathrm{LH}$ release and oestrus is thus not induced.

In one experiment, Killian et al. (1987) studied the effect of adrenalectomy (ADX) on puberty in gilts. The ADX gilts received daily injections of mineral- and glucorticoids to maintain them in as normal a physiological state as possible. Only 1 out of 11 ADX gilts compared to 9 out of 14 shamADX gilts showed oestrus within a 30 day period after relocation and boar exposure. The inability of the ADX gilts to respond to relocation/boar exposure with increased cortisol levels was discussed by Killian et al. (1987) as a reason for the higher frequency of absence of puberty among those gilts. No attention was paid to the loss of catecholamines after ADX in gilts.

The ovarian functions, including cyclic activity, steroid synthesis, follicular growth, se- lection of preovulatory follicles and ovulation, are controlled by the hypothalamopituitary-gonadal axis. However, modern studies suggest that adrenergic nerves participate in the control of ovarian function (see reviews: Burden 1985, Spicer 1986). Several studies have reported a close relationship between adrenergic axon terminals and epithelial cells of primordial follicles as well as growing follicles (see review: Burden 1985). Bahr \& Ben-Jonathan (1985) have found that catecholamine levels increase significantly in porcine follicular fluid before ovulation. One possible explanation of the present results is that an increased activity of the sympathetic nervous system with concomitantly raised levels of catecholamines in connection with transportation/relocation contribute to the stimulatory effect on puberty. A significant correlation between oestradiol-17 $\beta$ and cortisol levels was seen in the present study during oestrus. The cortisol level increased gradually during the prooestrus period and the first day of oestrus and then decreased. These results are in accordance with earlier studies by Asp \& Heap (1975). They reported high levels of cortisol in sows during oestrus. Becker et al. (1985b) found that serum cortisol levels were significantly higher in ovariectomized (OVX) gilts injected with oestradiol-benzoate (day 1) and showing oestrus on day 4 and 5, than in control OVX gilts given sunflower seed oil. The check of oestrus with boar may contribute to the raised levels of cortisol. Oestradiol receptors have been found in the motor area of the brain (see review: Maggi \& Perez 1985). During pro-oestrus, the levels of oestradiol-17 $\beta$ increase which must influence the motor area, causing the higher activity in the animals (Schenk 1967, Signoret 1970). The increased activity in the animals may also contribute to the raised cortisol levels. 


\section{Conclusion}

- The level of cortisol was significantly higher on the day of transportation than the following day. The CBG level decreased significantly the day after transportation.

- The levels of cortisol were markedly higher on day 1 and day 2 in gilts not showing oestrus than in gilts induced into oestrus by transportation.

\section{Acknowledgement}

This investigation was supported by grants from the Swedish Council for Forestry and Agricultural Research and the Farmer's research Council for Information and Development. The Department of Animal Breeding and Genetics is gratefully acknowledged for supplying the gilts.

Antiserum to ovine $\mathrm{LH}$ was kindly donated by dr. G. D. Niswender, Colorado State University, Fort Collins, USA. The authors are indebted to Dr. L. E. Reichert for supplying porcine LH for iodination and as standard.

\section{References}

Ash $R W$, Heap RB: Oestrogen, progesterone and corticosteroid concentrations in peripheral plasma of sows during pregnancy, parturition, lactation and after weaning. Endocrinology 1975, 64, 141-154.

Andersson A-M, Einarsson S, Edqvist L-E: Prepubertal LH, oestradiol-17 $\beta$ and progesterone pattern in gilts. Zbl. Vet. Med. A., 1983, 30, 438-446.

Bahr JM, Ben-Jonathan N: Elevated catecholamines in porcine follicular fluid before ovulation. Endocrinology 1985, 117, 620-623.

Barb CR, Kraeling RR, Rampacek GB, Fonda ES, Kiser TE: Inhibition of ovulation and LH secretion in the gilt after treatment with ACTH or hydrocortisone. J. Reprod. Fertil. 1982, 64, 85-92.

Becker BA, Nienaber JA, DeShazer JA, Hahn $G L$ : Effect of transportation on cortisol concentrations and on the circadian rhythm of cortisol in gilts. Am. J. Vet. Res. 1985a, 46, 1457-1459.
Becker BA, Ford JJ, Christenson RK, Manak RC, Hahn GL, DeShazer JA: Cortisol response of gilts in tether stalls. J. Anim. Sci. 1985b, 60, 264-270.

Boilert B, Edqvist L-E, Johansson EDB, Lindberg $P$, Martinsson $K$ : The influence of conjugated estrogens in radioimmunoassays using different antibodies against estradiol-17 $\beta$. Steroids 1973, 22, 891-894.

Bosu WTK, Edqvist L-E, Lindberg P, Martinsson $K$, Johansson $E D B$ : The effect of various dosages of lynestreol on plasma levels of oestrogen and progesterone during the menstrual cycle in rhesus monkey. Contraception 1976, 13, 677-684.

Burden $H W$ : The adrenergic innervation of mammalian ovaries. In Catecholamines as hormone regulators, eds. N. Ben Jonathan. J. M. Bahr and R. I. Weiner, Raven Press, New York 1985, pp. 261-278.

Dalin A-M, Eliasson L: Clinical, morphological and endocrinological studies in gilts with delayed puberty. Acta vet. scand. 1987, 28, 263 -269 .

Du Mesnil du Bouisson F, Signoret JP: Influences de facteurs externes sur le déclenchement de la puberté chez la truie. (Influences of external factors on the attainment of puberty in the gilt). Ann. Zootech. 1962, 11, 53-59.

Edqvist L-E, Johansson EDB: Radioimmunoassay of oestrone and oestradiol in human and bovine peripheral plasma. Acta Endocrinol. (Kbh.) 1972, 71, 716-730.

Edqvist L-E, Einarsson S, Larsson K, Lundström $K$ : Diurnal variations in peripheral plasma levels of testosterone, androstenone and cortisol in boars. Acta vet. scand. 1980, 21, 451453.

Eliasson L, Einarsson S, Lundeheim $N$ : Influence of halothane genotype and boar presence on puberty in gilts. J. Vet. Med. A. 1987, 34, 61 -68 .

Eriksson S, Sanne S, Thomke S: Fodermedlen. (Feedstuff). LT:s förlag, Stockholm 1972.

Johansson $G$, Olsson $K$, Häggendal J, Jönsson L, Thorén-Tolling $K$ : The effect of stress on myocardial cells and blood levels of catechol- 
amines in normal and amygdalectomized pigs. Can. J. comp. Med. 1982, 46, 176-182.

Killian DB, Kiesling DO, Wulff FP, Stewart ANV: Effects of adrenalectomy and glucorticoids on puberty in gilts reared in confinement. $J$. Anim. Sci. 1987, 64, 231-236.

Lundström K, Dahlberg E, Nyberg L, Snochowski $M$, Stendal $N$, Edqvist L-E: Glucocorticoid and androgen characteristics in two lines of pigs selected for rate of gain and thickness of backfat. J. Anim. Sci. 1983, 56, 401409.

Maggi A, Perez J: Minireview. Role of female gonadal hormones in the CNS: Clinical and experimental aspects. Life Sci. 1985, 37, 893 $-906$.

Moberg GP: Influence of stress on reproduction: Measure of well-being. In Animal stress, ed. G. P. Moberg, Waverly Press inc., Baltimore, Maryland 1985, pp. 245-265.

Niswender GD, Reichert Jr L-E, Midley Jr AR, Nalbandov $A V$ : Radioimmunoassay for bovine and ovine luteinizing hormone. Endocrinology 1969, 84, 1166-1173.

Niswender GD, Reichert Jr L-E, Zimmerman $D R$ : Radioimmunoassay of serum levels of luteinizing hormone throughout the oestrus cycle in pigs. Endocrinology 1970, 87, 576580.

Nyberg L, Lundström $K$, Edfors-Lilja I, Rundgren $M$ : Effects of transport stress on levels of cortisol, corticosteroid-binding globulin (CBG) and glucocorticoid receptors in pigs with different halothane genotypes. J. Amin. Sci. 1988, 66,1201-1211.

Paredis F: Onderzoekingen over vruchtbaarheid en kunstmatige inseminatie bij het varken. (Investigation of fertility and AI in pigs). PhD Thesis, Gent 1961.

Rodriguez H, Kunavongkrit A: Chronical venous catheterization for frequent blood sampling in unrestrained pigs. Acta vet. scand. 1983, $24,318-320$.

Rojanasthien $S$ : The effect of transportation and reloction in post-weaning anoestrous primiparous sows. Acta vet. scand., accepted.

SAS Institute Inc. SAS Users Guide, SAS Institute Inc. Cary, North Carolina 1985.
Schenk PM: An investigation into the oestrous symptoms and behaviour of sows. Z. Tierzücht. Züchtbiol. 1967, 83, 87-110.

Schilling $E$, von Rechenberg $W$ : Funktion der Nebennierenrinde und Ovulationsprozess beim Schwein. (The function of the adrenal cortex and the ovulation process in the pig). Zbl. Vet. Med. A, 1973, 20, 705-717.

Signoret JP: Reproductive behaviour of pigs. J. Reprod. Fertil., Suppl. 1970, 11, 105-117.

Siiteri PK, Murai JT, Hammond GL, Nisker JA, Raymoure WJ, Kuhn $R W$ : The serum transport of steroid hormones. Rec. Prog. Horm. Res. 1982, 38, 457-510.

Spencer, GSG, Wilkins LJ, Hallet KG: Hormone and metabolite changes in the blood of pigs following loading and during transport and their possible relationship with subsequent meat quality. In Proc. of the 30th European Meeting of Meat Res. Workers, Bristol 1984, 15-16.

Spicer LJ: Minireview. Catecholaminergic regulation of ovarian function in mammals: Current concepts. Life Sci. 1986, 39, 1701-1711.

Wildt DE, Fujimoto S, Spencer JL, Dukelow WR: Direct ovarian observation in the pig by means of laparoscopy. J. Reprod. Fertil. 1973, $36,541-543$.

\section{Sammanfattning}

Effekten av transport/omflyttning på plasmanivåerna av kortisol och CBG samt inträdande av könsmognad hos gyltor med försenad könsmognad.

Tjugosju gyltor av svensk Yorkshire-ras transporterades $12 \mathrm{~km}$ till kliniken. Blodprov togs på 8 gyltor (grupp A) i samband med transporten, hos de övriga 19 gyltorna (grupp B) togs ej blodprov då. Efter transporten undersöktes gyltorna med laparoskopi och venkatetrar opererades in. Blodprov togs 3 gånger per dag och brunstkontroll gjordes 2 gånger per dag. Efter en vecka upprepades laparoskopiundersökningen.

Tjugo gyltor (74 \%) visade brunst inom en vecka, i medeltal 5,4 dagar (4-7,5 dagar) efter transporten. Förhöjda östradiol-17ßnivåer sågs hos dessa gyltorna ca 2 dygn efter transporten. Kortisolnivån var signifikant högre $(\mathrm{p}<0.001)$ dag 1 (transport- 
dagen) än dag 2 och markant högre nivåer av kortisol sågs dag 1 och 2 hos de gyltor som ej visade brunst (2 gyltor) i jämförelse med de gyltor där brunst inducerades med hjälp av transporten. Skillnaden var signifikant dag $2(p<0.05)$. CBG nivån var signifikant sänkt $(\mathrm{p}<0.001)$ dag 2 hos alla 8 gyltorna. Under dag 3 till dag 8 var det ingen skillnad i kortisol nivån mellan dagarna (grupperna A och B, 27 gyltor) och ingen skillnad sågs $\mathrm{i}$ kortisol och $\mathrm{CBG}$ nivåene mellan gyltor som visade brunst $(20 \mathrm{st})$ och gyltor som ej visade brunst (7 st). En hypotes framfördes att en högre nivå av kortisol dag 1 och 2 hämnade inträdandet av brunst hos gyltor som ej visade brunst efter transport.

(Received November 30, 1987).

Reprints may be requested from: A.-M. Dalin, Department of Obstetrics and Gynaecology, Swedish University of Agricultural Sciences, P. O. Box 7039, S-750 07 Uppsala, Sweden. 